\title{
Ectopic thymic parathyroid adenoma
}

\author{
Dukhabandhu Naik, ${ }^{1}$ K Felix Jebasingh, ${ }^{2}$ Anish Jacob Cherian, ${ }^{3}$ Riddhi Dasgupta ${ }^{2}$
}

'Department of Endocrinology, Christian Medical College, Vellore, Tamil Nadu, India ${ }^{2}$ Department of Endocrinology, Diabetes and Metabolism, Christian Medical College, Vellore, Tamil Nadu, India ${ }^{3}$ Department of Endocrine Surgery, Christian Medical College, Vellore, Tamil Nadu, India

\section{Correspondence to} Dr Dukhabandhu Naik, drnaik2000@gmail.com

Accepted 8 September 2014

\section{DESCRIPTION}

Eighty per cent of primary hyperparathyroidism cases are caused by parathyroid adenoma while nearly $16 \%$ of ectopic parathyroid adenomas have been found to be the aetiology. ${ }^{1}$ A 50 -year-old man presented with pain in the back and knees for 4 years. He was initially evaluated elsewhere and was detected to have hypercalcaemia. No other investigations were done at the other facility. He was then evaluated in our institution for the persistence of hypercalcaemia and recently deranged renal function. His blood investigations revealed: serum calcium $12 \mathrm{mg} \%$ (normal (N) 8.3-10.4), phosphorus $1.8 \mathrm{mg} \%$ ( $\mathrm{N} 2.5-4.6$ ), creatinine $2 \mathrm{mg} \%$ (N 0.7-1.4), estimated glomerular filtration rate (eGFR) $56 \mathrm{~mL} / \mathrm{min} /$ body surface area (BSA), 25 (OH)-vitamin-D $20.03 \mathrm{ng} / \mathrm{mL}$ (N 20-32) and intact parathyroid hormone (iPTH) $644 \mathrm{pg} / \mathrm{mL}$ (N 8-74). An ultrasonography of his abdomen revealed mild nephrocalcinosis bilaterally. His bone mineral density showed a t score of -3 in forearm as compared with spine $(-1.2)$ and neck of femur $(-1.6)$. The ultrasonography of the neck did not show any parathyroid adenoma. $\mathrm{He}$ underwent a technetium-99m $\left({ }^{99 \mathrm{~m}} \mathrm{Tc}\right)$ sestamibi scan as well as a single photon emission CT (SPECT), which revealed an ectopic parathyroid adenoma below the lower pole of the right lobe of thyroid (figures 1 and 2). He underwent a focal parathyroid surgery via the cervical approach and the adenoma was located in the thymus; it was resected and removed. His intact parathyroid hormone (iPTH) and serum calcium levels measured $24 \mathrm{~h}$ after surgery, within normal limits. On the day of discharge, his corrected serum calcium level was $8.83 \mathrm{mg} \%$. At present, he is asymptomatic, on regular follow-up and has normal serum calcium levels.

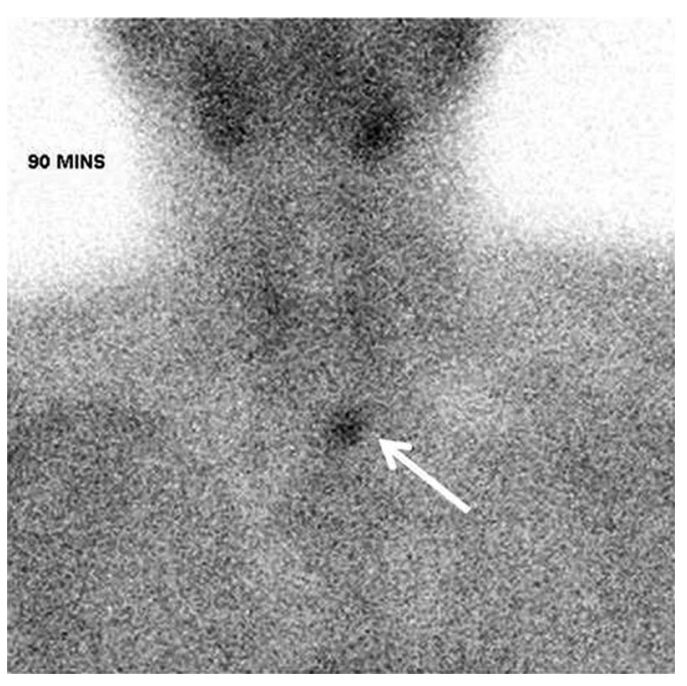

Figure 1 Technetium-99m ( $\left.{ }^{99 m} \mathrm{Tc}\right)$ sestamibi scan showing ectopic parathyroid uptake at $90 \mathrm{~min}$.

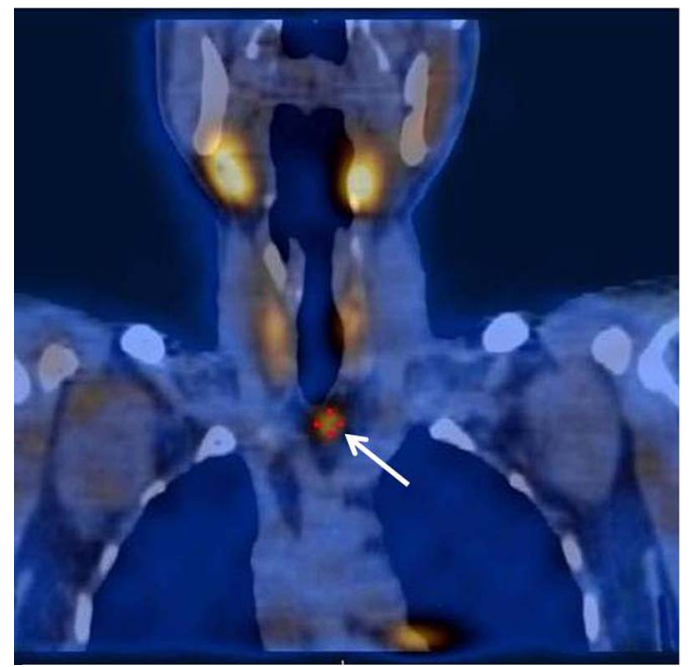

Figure 2 Single photon emission CT showing ectopic parathyroid adenoma below the right lobe of thyroid.

\section{Learning points}

- Although 99mTc sestamibi with single photon emission CT scanning has a high accuracy in localising parathyroid adenomas, including those that are ectopic, it may not always be positive in all cases, with a reported sensitivity varying between $70 \%$ and $100 \%$. $^{2} 3$

- Accurate preoperative localisation of parathyroid adenomas is essential for the success of the parathyroid surgery.

- Focus parathyroid surgery is adequate for cures other than bilateral neck exploration if the parathyroid adenoma is accurately localised. Thereby, it reduces the surgical morbidity and complications.

Contributors DN and KFJ collected the case details and prepared the manuscript. AJC and RD participated in the treatment of the patient.

Competing interests None.

Patient consent Obtained.

Provenance and peer review Not commissioned; externally peer reviewed.

\section{REFERENCES}

1 Noussios G, Anagnostis P, Natsis K. Ectopic parathyroid glands and their anatomical, clinical and surgical implications. Exp Clin Endocrinol Diabetes 2012;120:604-10.

2 Bernà L, Caixàs $A$, Piera J, et al. Technetium-99m-methoxyisobutylisonitrile in localization of ectopic parathyroid adenoma. J Nucl Med 1996:37:631-3.

3 Patel CN, Salahudeen HM, Lansdown M, et al. Clinical utility of ultrasound and 99mTc sestamibi SPECT/CT for preoperative localization of parathyroid adenoma in patients with primary hyperparathyroidism. Clin Radiol 2010;65:278-87. 
Copyright 2014 BMJ Publishing Group. All rights reserved. For permission to reuse any of this content visit http://group.bmj.com/group/rights-licensing/permissions.

BMJ Case Report Fellows may re-use this article for personal use and teaching without any further permission.

Become a Fellow of BMJ Case Reports today and you can:

- Submit as many cases as you like

- Enjoy fast sympathetic peer review and rapid publication of accepted articles

- Access all the published articles

- Re-use any of the published material for personal use and teaching without further permission

For information on Institutional Fellowships contact consortiasales@bmjgroup.com

Visit casereports.bmj.com for more articles like this and to become a Fellow 